\title{
ALGAE PROLIFERATION ON SUBSTRATES IMMERSED IN BIOLOGICALLY TREATED SEWAGE
}

\author{
Tomasz Garbowski ${ }^{1}$, Aleksandra Bawiec ${ }^{1}$, Krzysztof Pulikowski' ${ }^{1}$ Paweł Wiercik ${ }^{1}$ \\ 1 Wrocław University of Environmental and Life Sciences, Institute of Environmental Engineering, 50-363 \\ Wrocław, Grunwaldzki Square 24, Poland, e-mail: tomasz.garbowski@up.wroc.pl, aleksandra.bawiec@ \\ up.wroc.pl, krzysztof.pulikowski@up.wroc.pl, pawel.wiercik@up.wroc.pl
}

Received: 2016.09 .09

Accepted: 2016.10 .23

Published: 2017.01.01

\begin{abstract}
Due fast biomass production, high affinity for $\mathrm{N}$ and $\mathrm{P}$ and possibilities to $\mathrm{CO}_{2}$ sequestration microalgae are currently in the spotlight, especially in renewable energy technologies sector. The majority of studies focus their attention on microalgae cultivation with respect to biomass production. Fuel produced from algal biomass can contribute to reducing consumption of conventional fossil fuels and be a remedy for a rising energy crisis and global warming induced by air pollution. Some authors opt for possibilities of using sewage as a nutrient medium in algae cultivation. Other scientists go one step further and present concepts to introduce microalgal systems as an integral part of wastewater treatment plants. High costs of different microalgal harvesting methods caused introduction of the idea of algae immobilization in a form of periphyton on artificial substrates. In the present study the attention has focused on possibilities of using waste materials as substrates to proliferation of periphyton in biologically treated sewage that contained certain amounts of nitrogen and phosphorus.
\end{abstract}

Keywords: periphyton, microalgal biomass, artificial substrates, microalgal harvesting;

\section{INTRODUCTION}

Nowadays algae receive more and more attention. It is caused by capabilities of using their biomass as a feedstock in food production, renewable fuels and their usefulness to treat wastewater in wastewater treatment [Krzemieniewski et al. 2009; Rawat et al. 2010; Rahaman et al. 2011]. The ability of algae to remove contaminants as well as and sequestrate $\mathrm{CO}_{2}$ from atmospheric air, constitute wide perspectives for the use of biomass of these microorganisms in energy recovery [Prajapati et al. 2013]. Carbon dioxide is the substrate in photosynthesis reactions, and it can come from different sources, for instance exhaust gases or biogas [Boelee et al. 2012; Prajapati et al. 2013; Karło et al. 2013].

The majority of studies focus their attention on microalgae cultivation with respect to biomass production due to the necessity of decrease consumption of conventional fossil fuels because of rising energy crisis and global warming induced by air pollution [Kozieł, Włodarczyk 2011]. It is, undoubtedly, very important issue especially that algae possess a lot of favorable features in comparison with terrestrial energy crops, which are very popular in biofuel production. Among this features are high productivity, tolerance in relation to impurities, high lipid content in cells and limited competition with food crops (in algae cultivation arable lands are not required), hence it does not have a negative influence on global food supply [Rahaman et al. 2011; Rawat et al. 2011; Dębowski et al. 2013; Prajapati et al. 2013].

Some authors speculate on the possibilities of using sewage as a nutrient medium in algae cultivation. In this manner, it is possible to connect two economic sectors - renewable power engineering and wastewater treatment [Dębowski et al. 2013]. Other scientists go one step further and present concepts to introduce microalgal systems as an integral part of wastewater treat- 
ment plants [Krzemieniewski et al. 2009; Rawat et al. 2011; Boelee et al. 2012, Kwietniewska et al. 2012; Kloc and González 2012]. Applicability of algal biomass as a biological treatment factor is called phycoremediation. The main goal of this process is utilization of the rest of nutrients (mainly nitrogen and phosphorus) from sewage [Boelee et al. 2012].

According to Karło et al. 2013 and other authors, algae in sewage are able to decrease the amount of anthropogenic compounds (i.e. xenobiotic), heavy metals [Ugwu et al. 2008; Rawat et al. 2011] and also Escherichia coli bacillus, which, along with other gastrointestinal bacteria, is the most popular pathogenic microorganism in municipal wastewater [Bawiec et al. 2016a]. Algae ability to affect bacteria is not the direct consequence of microalgal activity but the prevailing conditions in algal aerobic open ponds (high $\mathrm{pH}$ value, high oxygen concentration and intensive insolation). Moreover, algae cultivation in sewage leads to reduction of their acidity. Furthermore, algae can be good indicators of water quality because of diverse living conditions [Rawat et al. 2011; Karło et al. 2013].

The origins of the use of algal ability to accumulate nutrients dates back to II World War. At that time, in Germany, cultivation of these organisms in open ponds was conducted. For the first time, algae were applied to phycoremediation in the USA in open ponds [Ugwu et al. 2008; Kozieł and Włodarczyk 2011; Kwietniewska et al. 2012; Karło et al. 2013]. Nowadays, living organisms are commonly used as a factor of wastewater treatment, especially in small wastewater treatment plants [Bawiec et al. 2016b].

Application of wastewater as a medium that provides nutrients for algal growth is economically feasible and significantly reduces the costs of cultivation [Rawat et al. 2011; Boelee et al. 2011; Prajapati et al. 2013] that along with required area, harvesting methods and $\mathrm{CO}_{2}$ supplementation is the crucial factor which determines profitability of this process [Rahaman et al. 2011; Prajapati et al. 2013; Dębowski et al. 2013].

During design devices for artificial algal cultivation, intensity and time of insolation, temperature requirement, nutrients concentration and $\mathrm{CO}_{2}$ availability should be taken into account [Rahaman et al. 2011; Kwietniewska et al. 2012; Karło et al. 2013]. The crucial factor having influence on microalgal growth, especially in wastewater treatment systems, is also the presence of bacterial consortium that uses oxygen excreted during photosynthesis for intensification of organic matter decomposition [Prajapati et al. 2013]. Moreover, bacterial metabolic processes lead to $\mathrm{CO}_{2}$ emission which is then used by algae [Karło et al. 2013]. This symbiosis is particularly important and should be applied in systems without $\mathrm{CO}_{2}$ supplementation.

Among a lot of algal cultivation objects only few can be practically used for biomass production for energy purposes [Ugwu et al. 2008]. The application of these devices results from high investments during building and operation. Their use in wastewater treatment would significantly exceed the whole treatment process costs.

Microalgal cultivation systems can be divided into two main types, namely: open ponds and closed photobioreactors that are significantly more expensive than open systems [Kwietniews$\mathrm{ka}$ et al. 2012]. These costs include the necessity of using artificial light sources, $\mathrm{CO}_{2}$ supplementation and stirring process. Those factors generate high energy needs [Krzemieniewski et al. 2009]. Among closed photobioreactors, tubular photobioreactors, cylindrical photobioreactors and flat-plate photobioreactors can be distinguished. [Ugwu et al. 2008; Kozieł and Włodarczyk 2011]. In open systems, besides natural tanks and lagoons, also artificial "raceway ponds" can be mentioned [Kozieł and Włodarczyk 2011; Karło et al. 2013; Prajapati et al. 2013].

The advantage of all types of closed systems is a possibility to better control the culturing conditions by means of partial isolation from external conditions, thereby receiving pure microalgal cultures. Furthermore, high productivity of photobioreactors is a reason why this solutions can be applied for biomass cultivation. Despite the presented advantages, these systems have serious drawbacks, besides high operational costs, appearance of hydrodynamic stress and limited light delivered into reactors during microalgal growth are possible [Ugwu et al. 2008; Krzemieniewski et al. 2009; Kozieł and Włodarczyk 2011; Kwietniewska et al. 2012].

Open ponds are very simple in construction and operation. They can be easily implemented into most wastewater treatment plants. However, in comparison to photobioreactors, controlling of cultivation process is difficult. In addition, evaporation and expose to contamination with other microorganisms limits their usefulness [Ugwu et al. 2008]. In open ponds long hydraulic retention time is required thereby these constructions have to be placed on a large area [Kwietniewska et al. 2012]. 
High pH fluctuations due to $\mathrm{CO}_{2}$ sequestration by algae belong to disadvantages of all microalgal cultivation systems. In order to keep a stable level of carbon dioxide additional technology of $\mathrm{CO}_{2}$ supplementation is required [Kozieł, Włodarczyk 2011]. Suitable reaction in closed reactors is important due to biological precipitation of carbonates. These compounds are responsible for water hardness and lime scale occurrence [Hammes and Verstraete 2002].

However, as reported by most authors, harvesting methods are a key and troublesome factor that determine the costs of algae cultivation [Krzemieniewski et al. 2009; Kwietniewska et al. 2012; Prajapati et al. 2013; Karło et al. 2013]. Problems with algae cultivation and their harvesting are connected with their specific features:

- unicellular structure of this organisms and microscopic size (several micrometers);

- considerable dilution of the culture (receiving of 1 ton of dry algal mass requires $200-5000$ $\mathrm{m}^{3}$ of cultivation medium)

- fast growth constitutes the need for frequent harvesting in order to avoid photosynthesis limitation [Rawat et al. 2011; Kwietniewska et al. 2012; Prajapati et al. 2013].

Among the present harvesting methods, the most popular are: centrifugation, filtration, sedimentation, flocculation and flotation [Rawat et al. 2011; Kwietniewska et al. 2012; Prajapti et al. 2013]. Advantages and disadvantages of those methods are presented in table 1 .

High costs of different microalgal harvesting methods caused introduction of an idea of algae immobilization in the form of periphyton on artificial substrates [Boelee et al. 2011]. This technology allows to time extension of nutrients removal from sewage and provides better retention of suspended solids particles [Łągiewka 1994; Karło et al. 2013].

In these systems, algae can grow on various substrates, such as: glass plates, nylon mesh, foil or raschel bags, but the most popular are special prepared polyethylene sheets that are induced into the sewage. Numerous papers demonstrate high efficiency of this substrate in nutrients removal [Łaggiewka 1994; Szlauer-Łukaszewska 2007; Kloc and González 2012]. Moreover, biostructures can be made from waste materials, which are cheap and easily accessible [Łaggiewka 1994]. Disadvantages of biofilm system include the possibility to detach biomass from artificial substrates. This causes bottom sediments formation and release nitrogen and phosphorus from biomass. It is the reason of secondary pollution in the treated sewage [Łągiewka 1994; Boelee et al. 2011; Boelee et al. 2012].

In the present study attention was focused on possibilities of using waste materials as substrates to proliferation of periphyton in biologically treated sewage that contained certain amounts of nitrogen and phosphorus.

Table 1. Comparison of different microalgal harvesting methods [Rawat et al. 2011; Prajapati et al. 2013; Karło et al. 2013]

\begin{tabular}{|c|c|c|}
\hline Harvesting method & Advantages & Disadvantages \\
\hline Centrifugation & $\begin{array}{l}\text { The fastest, universal and the most } \\
\text { efficient method. }\end{array}$ & $\begin{array}{l}\text { Requires a lot of energy and generates significant } \\
\text { costs, used only to obtain valuable substances } \\
\text { (pharmaceutical, chemicals etc.), may cause cells } \\
\text { damage. }\end{array}$ \\
\hline Filtration & $\begin{array}{l}\text { Relatively cheap and does not require } \\
\text { chemical reagents. }\end{array}$ & $\begin{array}{l}\text { The filters are exposed to clogging, most effective only } \\
\text { for colony-forming algae or species with large cells, the } \\
\text { filtered biomass consists pieces of the filtration layer. }\end{array}$ \\
\hline Sedimentation & Very simple and the cheapest method. & $\begin{array}{l}\text { It is usable for harvesting of cells with high density, } \\
\text { it is time-consuming and inefficient, requires using of } \\
\text { flocculants in order to increase the efficiency of algae } \\
\text { removal. }\end{array}$ \\
\hline Flocculation & $\begin{array}{l}\text { Is the process supporting other harvesting } \\
\text { methods, like filtration, centrifuging or } \\
\text { sedimentation. It is possible to use organic } \\
\text { reagents (non-toxic and edible). }\end{array}$ & $\begin{array}{l}\text { Some of the flocculants may cause increase of } \mathrm{pH} \\
\text { even up to 11. This method depends on wide spectrum } \\
\text { of factors e.g. salinity, pH or concentration of ions. } \\
\text { Flocculation reagents can be present in the recovered } \\
\text { biomass. Some types of reagents such as cationic } \\
\text { polymers are expensive. }\end{array}$ \\
\hline Flotation & $\begin{array}{l}\text { High efficiency, it is easily to conducted in } \\
\text { comparison with centrifuging or filtration. } \\
\text { The use of ozone proves cell lysis and } \\
\text { releases natural coagulation agents such } \\
\text { as biopolymers. }\end{array}$ & $\begin{array}{l}\text { Can be applied for small cells (with diameters below } \\
500 \mu m \text { ), requires application of flocculants. Problem } \\
\text { in open ponds due to contamination. Ozonation- } \\
\text { dispersed flotation is an expensive process. }\end{array}$ \\
\hline
\end{tabular}




\section{MATERIALS AND METHODS}

Studies on possibilities of algae proliferation on substrates immersed in biologically treated wastewater were conducted from February to May 2016 in Wrocław University of Environmental and Life Sciences. They covered benchscale experiments using glass tanks filled with biologically treated sewage. Artificial substrates were immersed in wastewater in order to proliferate algal biomass. Among the tested substrates were empty water bottles made of PET and polymeric erosion control mats applied to consolidate slopes or banks. These substrates were chosen because of their features:

- they are easily accessible and cheap;

- they have a structure that would be suitable for periphyton growth;

The substrates were introduced into three glass tanks, filled with sewage. Tank number I consisted of only mats, number II-bottles and number III- both substrates and also algae from the other culture. Algal growth was not supported by additional factors such as artificial insolation, heating or $\mathrm{CO}_{2}$ supplementation. During the experiment, room and sewage temperature, $\mathrm{pH}$ value, changes in forms of nitrogen and phosphorus content and biological diversity of periphyton were tracked.

Room temperature was measured by room thermometer whereas to measure temperature and $\mathrm{pH}$ value in sewage the multiparameter meter "YSI Professional Plus" were used, which gave opportunity for simultaneous measurement of temperature and $\mathrm{pH}$ value around the clock. The study of the sewage chemical composition covered the analysis of organic nitrogen, nitrates and phosphates. These analyses were made six times during the experiment duration in different time intervals.

To analyze the biological diversity of periphyton a reverse optical microscope was used. The camera captured images that were sent to the computer. Samples were collected from three glass tanks after observed changes in coloration of water or quantity of bottom and walls sediments in tanks (also on artificial substrates).

After about a month from the experiment onset, sewage was enriched by small amounts of effluents after nitrification (in a ratio 1:10) taken from digestion chambers of sewage sludge. These effluents were characterized by high nitrogen and phosphorus concentrations. This step was caused by low nutrients concentrations in wastewater used at the beginning of the experiment (hereinafter called "original sewage"). The purpose of this action was to increase the amounts of nutrients in glass tanks.

\section{RESULTS}

In the first stage of the experiment (before addition of effluents after nitrification), substantial biomass growth in any of three glass tanks was not observed. However, changes of sewage color from gray-green to dark brown was observed after 3 days from the beginning of the experiment. Moreover, on the bottles and mats surface, unstable and filamentous structures appeared (Figure 1). These structures drooped down and created large amounts of sediments after some time.

In tank III inoculated by algae, after about a 1.5 month since addition of wastewater after nitrification process, the appearance of green biofilm on tank's walls and bottles surface was observed (Figure 2). At the end of experiment, the presence of substantial amount of filamentous algae and diatoms (Figure 3) was found on glass and both substrates. Microscopic analysis indicated the presence of diatoms belonging to Bacillariophyceae (Figure 4), which tolerate alkaline environment ( $\mathrm{pH}$ value at that time was 8.66) and eutrophic water. Furthermore, these diatoms are good indicators of water quality [Noga et al. 2014]. The other two glass tanks consisted only dark brown sludge on the bottom, which after microscopic analysis, demonstrated trace amounts of microorganisms thereby, further research in these tanks were abandoned.

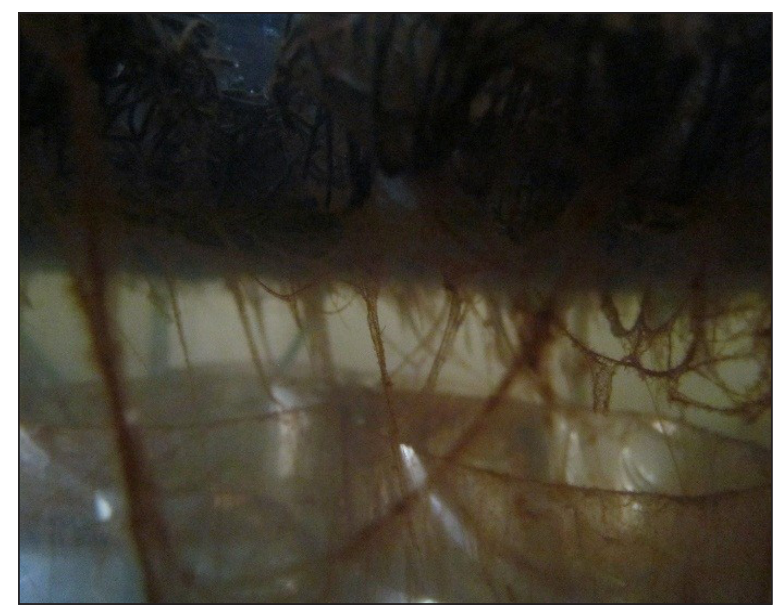

Figure 1. Filamentous structures attached to artificial substrates immersed in sewage [phot. Tomasz Garbowski] 


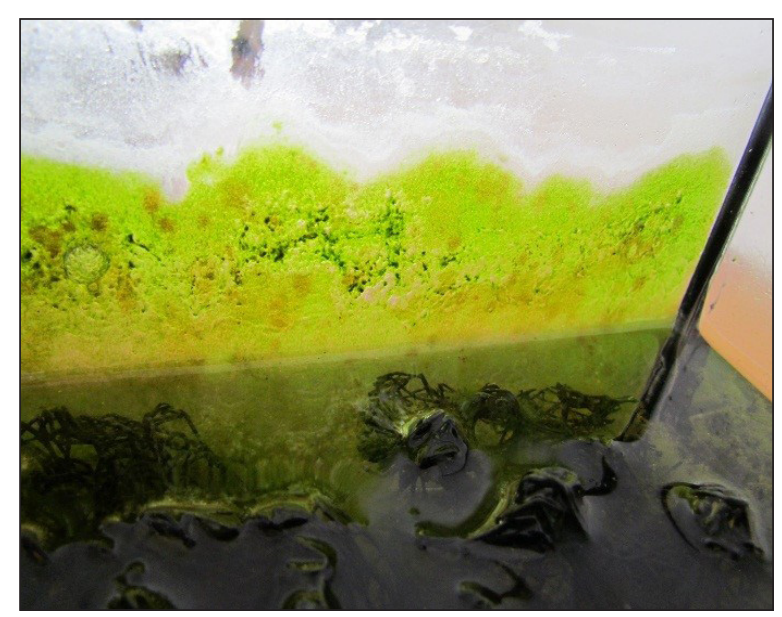

Figure 2. Green biofilm on glass wall in tank III and brown cluster of diatoms [phot. Tomasz Garbowski]

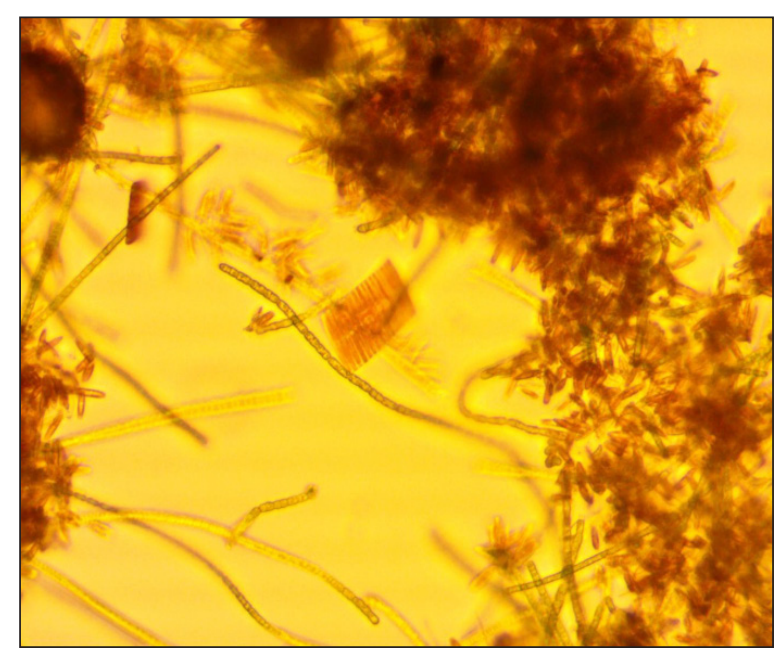

Figure 3. Filamentous algae and diatoms in sediments from tank III [phot. Tomasz Garbowski]

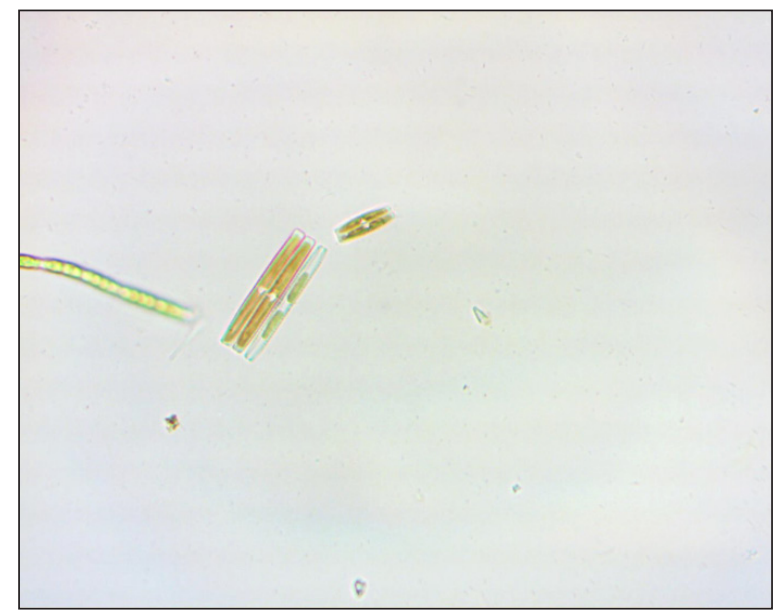

Figure 4. Bacillariophyceae diatoms under microscope [phot. Tomasz Garbowski].
The results of changes in nutrients concentration are presented in figure 5,6 and 7. Addition of concentrated effluents is responsible for large amounts of forms of $\mathrm{N}$ and $\mathrm{P}$ in samples after 21st March. As shown, phosphates (Figure 5) and nitrates (fig.6) concentrations increased in enriched sewage. Phosphates concentration was decreasing during the experiment in contrast to nitrates whose value reached $70.00 \mathrm{mgN} / \mathrm{dm}^{3}$ in all tanks at the end of the experiment.

Figure 7 shows that in the last sample, in glass tank with proliferated algae biomass, high increase of organic nitrogen concentration occurred. In the last sample the nitrates amount after pour of effluents after nitrification increased almost tenfold, in comparison with previous analysis. At the end of the experiment, enriched sewage had high concentrations of all nutrients in each of the tanks with respect to original wastewater.

The lowest temperature in wastewater was reported on the first day of experiment and it was $15.7^{\circ} \mathrm{C}$. This parameter increased during experiment. After two days, temperature increased by 3 degrees. The ambient temperature was always close to sewage temperature. Wastewater $\mathrm{pH}$ values were always above 7 (alkaline). $\mathrm{pH}$ value fluctuated during the day, however, at the end of experiment $\mathrm{pH}$ value $(\mathrm{pH}=8.66)$ was higher than initially $(\mathrm{pH}=7.77)$.

\section{DISCCUSION}

The study revealed that proliferation of algae biomass on artificial waste substrate is possible. However, the results were not complying with expectations due to slow algae growth and small amounts of periphyton on the bottles surface.

Initial lack of algae growth in sewage and on substrates could be caused by low nutrients concentration in the primary sewage. Total nitrogen concentration was $6.71 \mathrm{mgN} / \mathrm{dm}^{3}$ whereas total phosphorus concentration $3.66 \mathrm{mgP} / \mathrm{dm}^{3}$. In research conducted by Dębowski et al. 2013, the authors used effluents from sediments digestion that consisted ca. $50.0 \mathrm{mg} / \mathrm{dm}^{3}$ of total nitrogen and $16.0 \mathrm{mg} / \mathrm{dm}^{3}$ of total phosphorus as a nutrient medium for algal growth. Hence, the addition of sewage with high concentrations of nutrients during the experiment could cause subsequent algal growth.

As reported by Dębowski et al. [2013], negative influence on biofilm growth may have also 


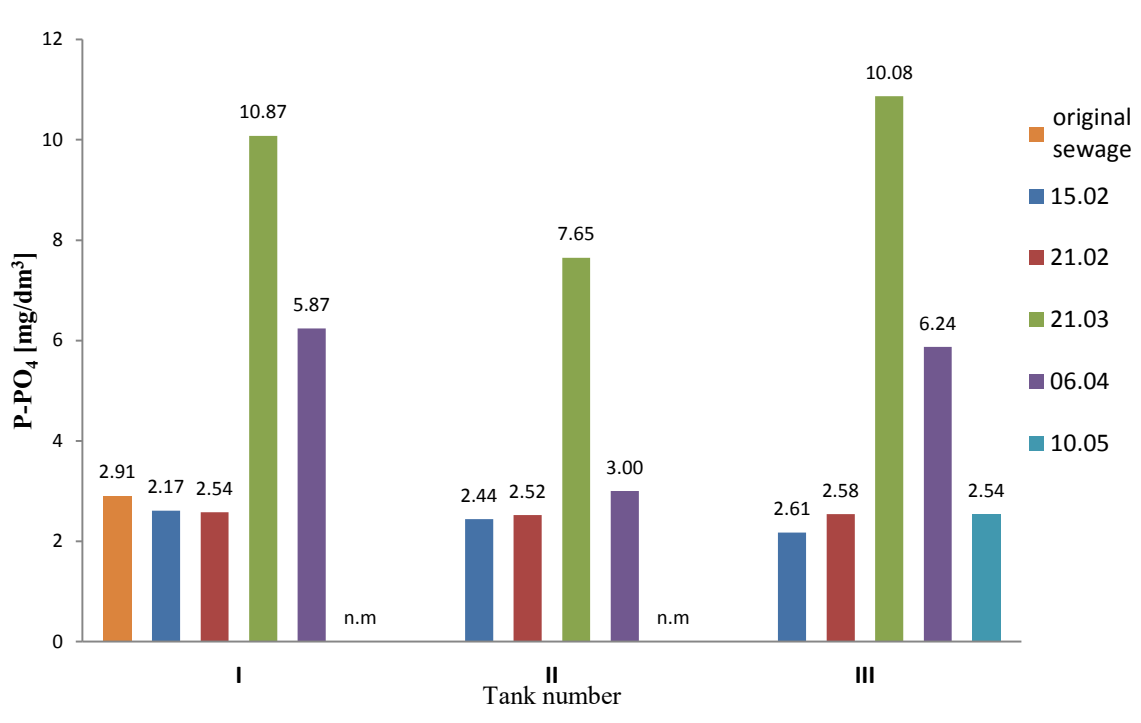

Figure 5. Changes in phosphates concentration

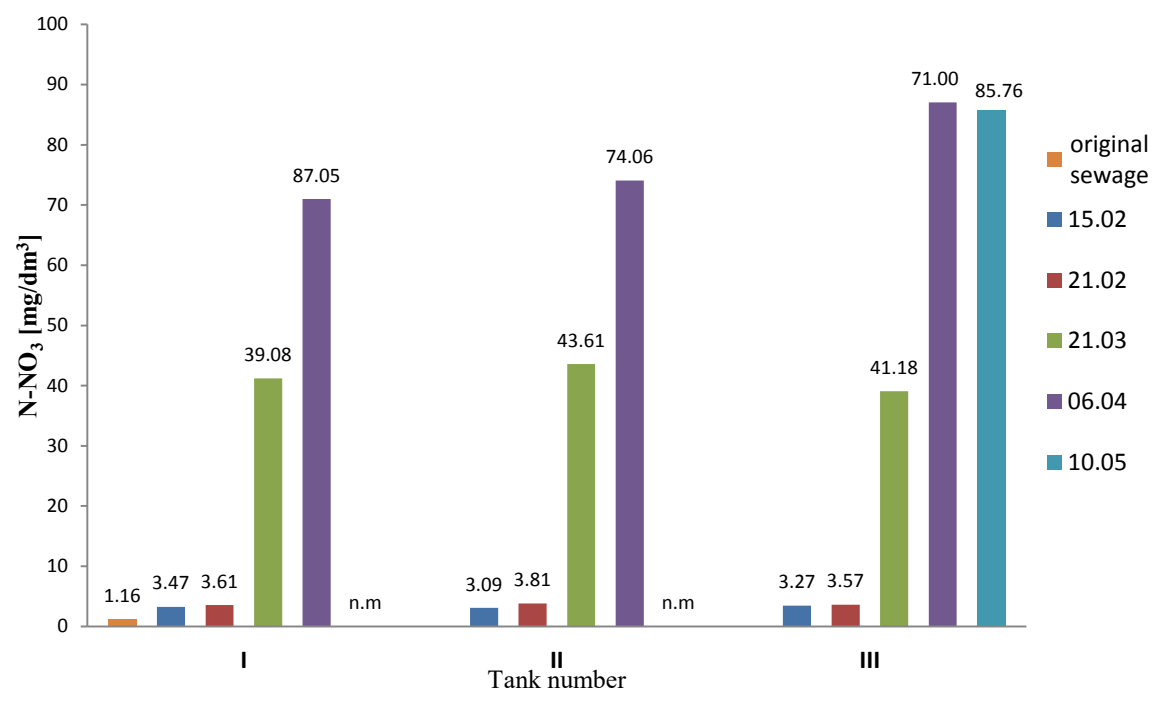

Figure 6. Changes in nitrates concentration

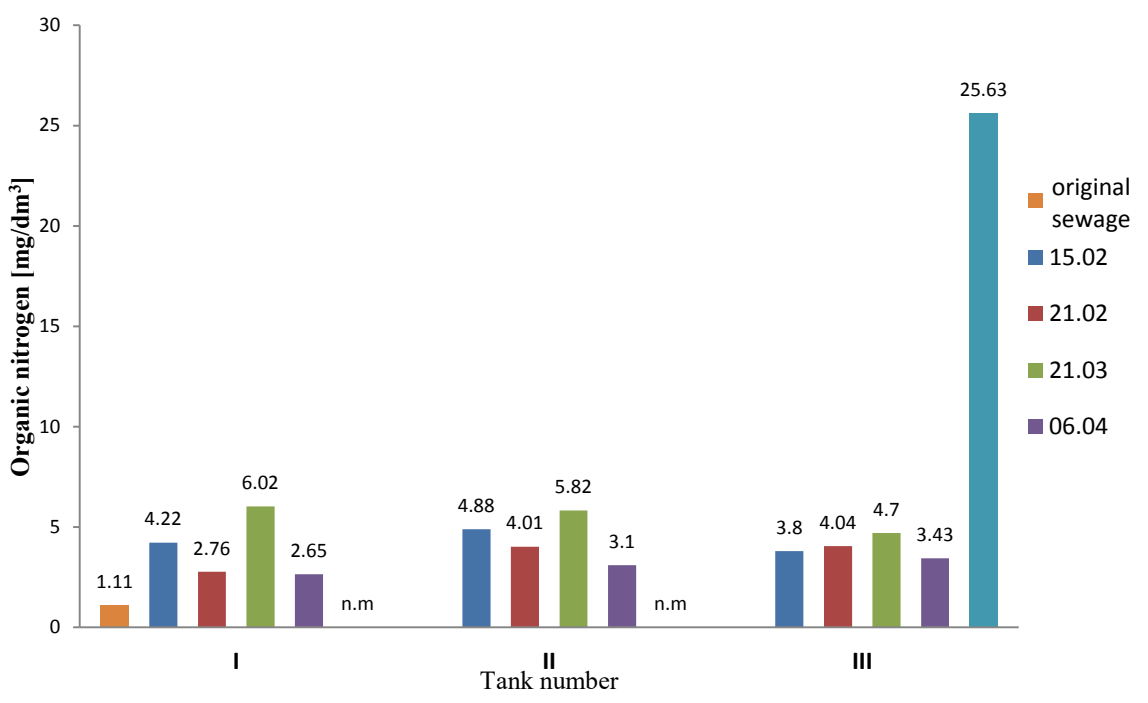

Figure 7. Changes in organic nitrogen concentration 
been attributed to low temperature and insufficient amount of $\mathrm{CO}_{2}$. Numerous papers present that optimal temperature for algal cultivation depends on the algal species and it is from 20 to even $40^{\circ} \mathrm{C}$ [Koziel, Włodarczyk 2011; Boelee et al. 2011; Kwietniewska et al. 2012]. Hence, initial temperature in conducted experiments (temperature $16-18^{\circ} \mathrm{C}$ ) could be a limiting factor for periphyton forming. Moreover, winter season in which the first stage of experiment was conducted (time before pour of effluents after nitrification) is unfavorable for wastewater treatment organisms. As reported by Bawiec et al. [2016b], in winter decrease efficiency of nutrients from sewage was occurred.

Another important parameter in algal cultivation is carbon dioxide which is an essential compound for all photosynthetic organisms [Rahaman et al. 2011]. $\mathrm{CO}_{2}$ is, in fact, main substrate for this process and the source of chemical energy. Microalgae are able to absorb $1.65-1.83 \mathrm{~kg}$ of carbon dioxide per $1 \mathrm{~kg}$ of produced biomass [Kozieł and Włodarczyk 2011; Kwietniewska et al.2012; Prajapati et al. 2013]. It is favorable from the viewpoint of air protection because algae are able to take part in air purification from $\mathrm{CO}_{2}$ along with biomass production. The source of carbon dioxide for algae can be the ambient air, diluted carbonates, exhaust gases (after removal of $\mathrm{SO}_{x}$ and $\mathrm{NO}_{x}$ compounds) or biogas from organic matter digestion for instance sewage sludge [Rahaman et al. 2011; Prajapati et al. 2013]. Therefore, the possibility of dosing pure $\mathrm{CO}_{2}$ in further study should be considered.

Besides the above- mentioned parameters, Algae need light that is responsible for right photosynthesis process [Prajapati et al. 2013]. Numerous papers confirm that low temperature and low insolation have negative influence on nutrients uptake capacity in algal cultivation [Boelee et al. 2012]. Under temperate climate conditions, differences between day length in winter and summer appear, hence, initial lack of algal growth could be induced by this factor. It is likely because, along with spring arrival and nutrients addition, in tank III biofilm forming process has begun.

Because of low photosynthesis efficiency in temperate zone countries, the use of algal biomass in nutrients removal can be supporting system in wastewater treatment plants, especially in the summer season.
In the presented results in the last stage of experiment, organic nitrogen concentration increase was observed in tank number III. Organic nitrogen concentration increase and biomass occurrence were simultaneously observed. The analysis of this phenomenon shows that high concentration of this form of nitrogen is the result of detached pieces of biomass from substrates that formed bottom sediments. It has caused secondary pollution. The results obtained by Szlauer-Łukaszewska 2007 show that periphyton development passes during three distinct stages: initial, intermediate and mature. Mature stage is reached after about 12 weeks from the start of the biofilm forming process. It is assumed that in mature stage biostructure reaches its climax stadium. Therefore, microorganisms metabolic processes are slowed, nitrogen uptake is limited and periphyton layer has a significant thickness. It causes biostructure detachment from substrates and release of previously accumulated contaminants. In present study, increased amounts of organic nitrogen in sewage were observed after 14 weeks from the start of experiment. Hence, at this time, biofilm degradation process could be started.

In contrast to nitrates, phosphates concentration was reducing during the experiment (after addition of effluents after nitrification). This results from the accumulation of this nutrient in algal biomass and lack of its secretion. Initial nutrients concentration persisted on a constant level. Addition of sewage with high nitrogen and phosphorus concentration induced fluctuations in chemical parameters. It is likely that sewage after nitrification and higher temperature stimulated algal growth by created suitable conditions for their development.

\section{CONCLUSIONS}

1. Due to their capability to fast biomass production (they can double up biomass after 24 hours) [Krzemieniewski et al. 2009; Rahaman et al. 2011], high affinity for $\mathrm{N}$ and $\mathrm{P}$ and possibilities to $\mathrm{CO}_{2}$ sequestration, microalgae are in the spotlight, especially in renewable energy technologies.

2. Among the most expensive factors in microalgae cultivation is algae separation process from water column. For instance, according to Oilgae Report 2009, the cost of algae separation by flocculation amounts ca. 1000 dollars 
for ca. 4 million liters of cultivation medium. So far, methods that are used generate high energy consumption costs, thus they are unprofitable on a large scale. Separation methods, which can be applied in wastewater treatment plants, include algae immobilization on artificial substrates. Periphyton growth allows for suspended particles retention and nutrients removal throughout accumulation of $\mathrm{N}$ and $\mathrm{P}$ within microorganism cells.

3 . The study shows that applied artificial substrates are not really applicable for algal biomass proliferation because of small amount of algal cells in sewage and slow biofilm growth. Despite long-term experiment, satisfactory results related with periphyton development in glass tanks were not reached. Probably, it was caused by insufficient nutrients amounts in the first stage of the experiment. Moreover, other limiting factors like too low ambient temperature and carbon dioxide concentrations in sewage, small light intensity in winter season and also lack of artificial illuminate had negative effects on algal cultivation.

4. In the future next series of experiments under more controlled conditions and with other artificial substrates types are planned. Moreover, it should be noted that algae can accumulate substantial amounts of $\mathrm{CO}_{2}$. Suitable dose of carbon dioxide may have a positive influence on biomass proliferation. The presented results of study, suggest that under natural conditions in temperate climates, nutrients remove process by algal biomass can be used by only some part of year, namely in summer season. Hence, the application of this technology as tertiary wastewater treatment all over the year may be unfeasible.

5. The conducted research partly confirms the assumption that proliferation of algal biomass on waste substrates is possible and can be used in wastewater treatment. However, during microalgal cultivation, adequate conditions must be provided. Moreover, additional elements such as $\mathrm{CO}_{2}$ supplementation and artificial illumination would be an favorable option. Issues associated with algal biomass are wide and its precise examination is required. In the future, artificial substrates and biomass production can be the open way to crate environmentally friendly technologies which will be applied on a large scale and may reduce harmful effects of human activity.

\section{REFERNCES}

1. Bawiec A., Pawęska K., Jarząb A., 2016. Changes in the microbial composition of municipal wastewater treated in biological processes, Journal of Ecological Engineering, 17(3), 41-46.

2. Bawiec A., Pawęska K., Pulikowski., 2016. Seasonal changes in the reduction of biogenic compounds in wastewater treatment plants based on hydroponic technology, Journal of Ecological Engineering, 17(2), 128-134.

3. Boelee N.C., Temmink H., Janssen M., Buisman C.J.N., Wijffels R.H., 2012. Scenario Analysis of Nutrient Removal from Municipal Wastewater by Microalgal Biofilms, Water, 4(2), 460-473.

4. Boelee N.C., Temmink H., Janssen M., Buisman C.J.N., Wijffels R.H., 2011. Nitrogen and phosphorus removal from municipal wastewater effluent using microalgal biofilms, Water Research, 45(18), 5925-5933.

5. Dębowski M., Zieliński M., Krzemieniewski M., Dudek M., Grala A., 2013. Możliwość namnażania biomasy glonów na bazie odcieku pochodzącego z odwadniania osadów pofermentacyjnych, Rocznik Ochrona Środowiska, Vol. 15, 1612-1622.

6. Hammes F., Verstraete W., 2002. Key roles of pH and calcium metabolism in microbial carbonate precipitation, Environmental Science \& Bio/Technology, Vol. 1(1), 3-7.

7. Karło A., Ziembińska A., Surmacz-Górska J., 2013. Glony na oczyszczalni ścieków, Technologia wody, 2(22), 10-13.

8. Kozieł W., Włodarczyk T., 2011. Glony-Produkcja Biomasy, Acta Agrophysica, 17(1), 105-116.

9. Kloc J., Mendoza González I., 2012. The Study of Biological Wastewater Treatment through Biofilm Development on Synthetic Material vs. Membranes, Worcester Polytechnic Institute Report, 1-72.

10. Krzemieniewski M., Dębowski M., Zieliński M., 2009 Glony jako alternatywa dla lądowych roślin energetycznych, Czysta Energia, Vol. 9, 25-27.

11. Kwietniewska E., Tys J., Krzemińska I., Kozieł W., 2012. Microalgae-cultivation and application of biomass as a source of energy: a review, Acta Agrophysica Monographiae, Vol. 2, 1-108.

12. Łągiewka W., 1994. Zastosowanie biostruktur do oczyszczania wód powierzchniowych i ścieków, Ochrona Środowiska, Vol. 3-4, 49-52.

13. Noga T., Kochman N., Peszek Ł., Stanek-Tarkowska J., Pajączek A., 2014. Diatoms (bacillariophyceae) in rivers and streams and on cultivated soils of the podkarpacie region in the years 2007-2011, Journal of Ecological Engineering, 15(1), 6-25.

14. Oilgae Report - Academic Edition. 2009. 
15. Prajapati S.K., Kaushik P., Malik A., Vijay V.K., 2013. Phycoremediation coupled production of algal biomass, harvesting and anaerobic digestion: Possibilities and challenges, Biotechnology Advances, 31(8), 1408-1425.

16. Rawat I., Ranjith Kumar R., Mutanda T., Bux F., 2011. Dual role of microalgae: Phycoremediation of domestic wastewater and biomass production for sustainable biofuels production, Applied Energy, 88(11), 3411-3424.
17. Rahaman M.S.A, Cheng L-H., Xu X-H., Zhang L., Chen H-L., 2011. A review of carbon dioxide capture and utilization by membrane integrated microalgal cultivation processes, Renewable and Sustainable Energy Reviews, 15(8), 4002-4012.

18. Szlauer-Łukaszewska A., 2007. Succession of Periphyton Developing on Artificial Substrate Immersed in Polysaprobic Wastewater Reservoir, Polish J. of Environ. Stud. 16(5), 753-762. 